\title{
In Defence OF THE CISG
}

\section{Christopher KeE AND Edgardo Muñoz}

In this article, the authors respond to certain criticisms made against the 1980 Vienna Convention on Contracts for the International Sale of Goods (the 'CISG') and explain what they perceive as the shortcomings of, and impediments to, a particular model of a proposed new global code. A goal of both the CISG and the proposed global code is to create an environment which promotes international trade. Predictability in the law is a fundamental element to achieve such an environment. The CISG has been criticised as failing to provide such predictability. It has been suggested that it has not been uniformly interpreted, contains internal inconsistencies and allows countries to establish varying mini-codes. While there may be some merit in some of these criticisms there is also much that is overstated and wrong. The CISG may not be a perfect instrument. However, it has been widely accepted and that alone makes it a strong basis from which to develop. A global code applied with absolute uniformity throughout the world might provide predictability. However, such a uniform law is unrealistic and, in any event, undesirable. The authors propose a more realistic solution. The law should be the framework upon which individually nuanced contracts could be built. Predictability is obtained by developing and establishing avenues of communication. It is also obtained by developing and establishing means of explaining and understanding the concepts upon which the framework has been built. The CISG allows for all of this.

\section{INTRODUCTION}

The 1980 Vienna Convention on Contracts for the International Sale of Goods (the 'CISG') is the law of all Australian States and Territories. It is enacted at

\footnotetext{
* Christopher Kee, BA (Hons) LLB (Deakin), Pro Cert Arb (Adelaide), Grad Dip Laws (UQ), Barrister and Solicitor, Supreme Court (Vic), Supreme Court (NSW), High Court of Australia; Adjunct Professor, City University of Hong Kong; Honorary Fellow, Deakin University, Australia; Senior Research Assistant, Global Sales Law Project, University of Basel, Switzerland. Edgardo Muñoz, Lic (Mexico), DEUF (Lyon), LLM (Liverpool), Admitted Lawyer in Mexico, Research Assistant, Global Sales Law Project, University of Basel, Switzerland. The views expressed in this paper are the authors' own and not those of their universities.
} 
a state level through uniform enabling legislation. ${ }^{1}$ As a UN convention the CISG entered into force on 1 April 1989. The CISG has $74^{2}$ state parties and is in force in 72 of those, making it one of the most adopted international private law conventions. Unfortunately, Australia does not have a particularly good reputation when it comes to understanding or applying the CISG. When a contract is of the type to which the CISG applies it is quite often the case that the parties, counsel and the courts remain unaware of the CISG's application until the end of the trial. ${ }^{3}$ This is perhaps in part due to the fact that there is no mention of the CISG in the respective Goods, or Sale of Goods, Acts, as the case may be. Nevertheless, as it is Australian law it should be defended against particularly unfair critiques.

We read with interest Christopher Scheaffer's article published in the Fall 2007 edition of Cardozo Journal of International and Comparative Law, and entitled 'The Failure of the United Nations Convention on Contracts for the International Sale of Goods and a Proposal for a New Uniform Global Code in International Sales Law'. ${ }^{4}$ As the title suggests, Scheaffer is very critical of the convention.

Scheaffer identifies four failures of the CISG as a uniform code. There is a fifth criticism, which Scheaffer makes in his introduction ${ }^{5}$ but does not elaborate upon, that is, its internal contradictions.

First, in Scheaffer's view, CISG Article 7 is in itself an impediment to uniformity due to 'the provision's ambiguity and the absence of a clear hierarchal methodology of interpretation'.

\footnotetext{
${ }^{1}$ Sale of Goods (Vienna Convention) Act 1987 (Vic); Sale of Goods (Vienna Convention) Act 1987 (Tas); Sale of Goods (Vienna Convention) Act 1987 (ACT); Sale of Goods (Vienna Convention) Act 1986 (Qld); Sale of Goods (Vienna Convention) Act 1986 (NSW); Sale of Goods (Vienna Convention) Act 1986 (SA); Sale of Goods (Vienna Convention) Act 1986 (WA); Sale of Goods (Vienna Convention) Act 2007 (NT).

${ }^{2}$ United Nations Commission on International Trade Law, Status: 1980- United Nations Convention on Contracts for the International Sale of Goods, United Nations Commission on International Trade Law $<$ http://www.uncitral.org/uncitral/en/uncitral_texts/sale_goods/1980CISG_status.html > at 11 August 2009.

${ }^{3}$ See Italian Imported Foods Pty Ltd v Pucci SRL [2006] NSWSC 1060 (Unreported, Malpass AsJ, 13 October 2006); Downs Investments Pty Ltd v Perwaja Stell SDN BHD [2002] 2 Qd R 462; Perry Engineering Pty ltd v Bernold AG [2001] SASC 15 (Unreported, Burley J, 1 February 2001).

${ }^{4}$ Christopher Scheaffer, 'The Failure of the United Nations Convention on Contracts for the International Sale of Goods and a Proposal for a New Uniform Code in International Sales Law' (2007) 15(2) Cardozo Journal of International and Comparative Law 461.

${ }^{5}$ Scheaffer, above n 4, 462.
} 
Second, Scheaffer suggests that the CISG has suffered from language difficulties arising out of the six official language versions that 'greatly complicate the goal of uniformity'. ${ }^{7}$

Scheaffer's third basis of criticism comes from what he alleges are the multitude of 'mini-codes' resulting from the ability of the adopting countries and contractual parties 'to choose when and how the governing law will be applicable'. ${ }^{8}$

Fourth, in Scheaffer's view the existence of diverging interpretations and conflicting case law makes the CISG 'impractical, undermining uniformity in international sales law'. ${ }^{9}$

Finally, there is a fifth criticism which Scheaffer makes in his introduction ${ }^{10}$ but does not elaborate upon, that is, the supposed internal contradiction between CISG Articles 14(1) and 55.

While we find ourselves in agreement with some of Scheaffer's concerns, we nevertheless cannot agree with his assessment that the CISG has been a failure and so have been moved to write this defence. Similarly, we do not share the view that a new uniform global code in international sales law is a solution to the problems that Scheaffer identifies. We see many difficulties with that approach and instead believe that there are more realistic and achievable alternatives that will deliver the desired outcome. In our view the answer lies in better education and understanding, improved avenues of communication and the dissemination of knowledge to all interested parties. The Global Sales Law project, in which we are both involved and which we describe in the concluding part of this paper, is an initiative specifically designed to achieve these goals.

Part I of this paper responds to the criticisms raised by Scheaffer on the current role of the CISG. We then, in Part II, explain what we perceive as the shortcomings of and impediments to a new global code. Part III very briefly addresses the role of other harmonisation initiatives currently undertaken at an international level, and, finally, Part IV proposes a more realistic solution to the current problems faced by judges, legal practitioners, academics and students when dealing with international sales law matters.

\footnotetext{
${ }^{6}$ Ibid 470.

${ }^{7}$ Ibid 474 .

${ }^{8}$ Ibid 476.

${ }^{9}$ Ibid 479.

${ }^{10}$ Ibid 462, note 7.
} 


\section{PART I: THE CISG - ITS PROBLEMS AND MERITS}

Scheaffer is right when he suggests that the world has become a small place. ${ }^{11}$ No one could reasonably deny that in the last 30 years the growth of international trade, together with the new developments in technology, have created a much closer interaction between countries, societies and people in general. ${ }^{12}$ Commerce is at the base of the phenomenon, since many of the improvements in technology and our lives in general have been motivated by profit. ${ }^{13}$ The same may also be said about unification endeavours and achievements in the area of private law. Lex Mercatoria compilations, uniform or model laws undertaken by organisations such as UNIDROIT, UNCITRAL, The Hague Conference or the International Chamber of Commerce, among others, all have the basic aim of facilitating amicable trade and minimising or settling disputes between traders. ${ }^{14}$ A predictable system which is understood and appreciated by everyone involved decreases expenses and increases profits. ${ }^{15}$ In addition, there are many important 'extraeconomic' effects that result from an increase in international trade. The notion of interdependency theory ${ }^{16}$ - the idea that countries are less likely to go to war with each other if they are trading partners - has, by and large, proved to be true. So, while we agree with Scheaffer's aspiration towards harmonisation of the law, we do not necessarily share the sentiment that this must be achieved by a uniform code. Harmony does not mean that everything has to be identical. Rather, it means that things must be able to work together. Certainly, a uniform code applied uniformly would achieve much of what Scheaffer is seeking, but it is unrealistic to believe that this will ever occur. Although we take issue with many of the criticisms Scheaffer levels at the CISG, we do agree that it has not been interpreted uniformly. However, we fail to see how or why the proposed Global Code would be any different from the CISG, and we fail to see why this is necessarily a bad thing. Perhaps this

\footnotetext{
${ }^{11}$ Ibid 461.

${ }^{12}$ See Globalization for Development: The International Trade Perspective, [vii] UNCTAD/DITC/2007/1 (2008) <http://www.unctad.org/en/docs/ditc20071_en.pdf> at 11 August 2008.

${ }^{13}$ See Ann Florini, The Coming Democracy: New Rules For Running A New World (2005).

${ }^{14}$ On the benefits of private international law instruments see Sandeep Gopalan, 'A Demandeur-Centric Approach to Regime Design in Transnational Commercial Law’ (2008) 39 Georgetown Journal of International Law1, 7 <http://ssrn.com/abstract=1105225> at 11

August 2009.

${ }^{15}$ Ibid 4.

${ }^{16}$ See Scott Burchill et al, Theories of International Relations $\left(2^{\text {nd }}\right.$ ed, 2001).
} 
suggests that we belong to the 'new formalist' camp of legal theory, ${ }^{17}$ although here is not the place to have a theoretical debate.

The CISG was drafted by jurists from all over the world who specialise in the law of sales. ${ }^{18}$ The Convention reflects the consensus reached by the members of the 1980 United Nations Conference on Contracts for the International Sale of Goods, based on 12 years of work by UNCITRAL and the various governmental delegates who had taken part in the relevant Working Group. ${ }^{19}$ Naturally, as every jurisdiction has its own views on the fundamental rules for sales contracts, most provisions of the CISG needed to reflect common principles. $^{20}$ This was only possible after the comparative study of different codes and statutes. ${ }^{21}$

As previously stated, Scheaffer identifies five reasons for the failure of the CISG as a uniform code:
(A) Deficiencies in CISG Article 7;
(B) Language Problems;
(C) The opportunity for 'opting out' of the CISG;
(D) Misapplication of the CISG by courts; and
(E) internal contradictions.

We will address them in the same order.

\footnotetext{
${ }^{17}$ For a very clear and easily understood critique of 'new formalism' see Mark Movsesian, 'Rediscovering Williston' (2005) 62 Washington and Lee Law Review 207.

${ }^{18}$ In this regard see the Travaux préparatoires of the CISG and note the representatives from many different jurisdictions who participated in the drafting.: United Nations Commission on International Trade Law, Travaux Prépatoires (2009)

$<$ http://www.uncitral.org/uncitral/en/uncitral_texts/sale_goods/1980CISG_travaux.html> at 11 August 2009.

${ }^{19}$ For a detailed description on the 1980 United Nations Conference see Texts adopted by the United Nations Conference on Contracts for the International Sale of Goods [149], UN Doc A/CONF.97/18 (1980) <http://www.uncitral.org/pdf/english/yearbooks/yb-1980-e/vol11-p149150-e.pdf $>$ at 11 August 2009.

${ }^{20}$ Peter Schlechtriem and Ingeborg Schwenzer, Commentary on the UN Convention of the International Sale of Goods (CISG) (2nd ed, 2005) 2.

${ }^{21}$ Ibid 6.
} 


\section{A CISG Article 7}

In Scheaffer's view, CISG Article 7 is itself an impediment to uniformity. We certainly agree that it has been the subject of controversy and is understood differently by different people. However, we believe that Scheaffer's critique has misunderstood the debate and overstated its significance.

For the sake of clarity we feel it is important to reproduce Article 7 in its entirety.

\section{Article 7}

(1) In the interpretation of this Convention, regard is to be had to its international character and to the need to promote uniformity in its application and the observance of good faith in international trade.

(2) Questions concerning matters governed by this Convention which are not expressly settled in it are to be settled in conformity with the general principles on which it is based or, in the absence of such principles, in conformity with the law applicable by virtue of the rules of private international law.

Scheaffer identifies two issues with Article 7(1): first, the lack of a definition of good faith, and, second, the difficulty of determining where and upon whom a good faith duty is imposed. We will address the second of these points first, as our response to it will largely negate the first issue as well.

The debate as we see it is whether Article 7(1) imposes a positive obligation on the parties to act in good faith, or whether it is a statement that the Convention must be interpreted according to the observance of good faith in international trade. ${ }^{22}$ We argue for the latter. What is significant in our view is the phrase at the very beginning of the Article 'In the interpretation of the Convention'. Scheaffer does not place emphasis on these words and does not reproduce them when quoting from the Article. Further, Scheaffer cites Professor Schlechtriem as supporting the view that Article 7 imposes an obligation directly on the parties. We interpret Schlechtriem very differently that is, we believe he shared our view.

\footnotetext{
${ }^{22}$ For a further explanation of the debate see Troy Keily, 'Good Faith and Vienna Convention on Contracts for the International Sale of Goods (CISG)' (1999) 3 Vindobona Journal of International Commercial Law and Arbitration 15.
} 
The meaning of the reference to 'good faith' is controversial, but this phrase is not unique to Article 7 and can be found in other Conventions or drafts of Conventions as well. As its history shows, the origin of that term lies in the reference to good commercial practice and it was initially intended to govern not the interpretation of the Convention's rules by courts, but the parties' conduct. But such opinions, which are influenced not least of all by the German understanding of the principle of Treu und Glauben and its bearing on legal texts as well as individual contracts, cannot be regarded as having prevailed. The maxim of 'observance in good faith in international trade', therefore, concerns the interpretation of the Convention only. ${ }^{23}$

We argue that, when considered in this light, the need for a precise and unambiguous definition of 'good faith' disappears. 'Good faith' can be understood as a broad and general maxim, in the same way that general notions of 'equity' in a broad sense might be referred to by a common law lawyer. As nothing is to be judged by the standard, a precise definition is not necessary. In light of the discussion below, we feel it important to note that this interpretation also reconciles a linguistic difference between the official Spanish, French and Arabic versions of the CISG and the English version. ير اعى Each of those versions adds an extra verb ('asegurar', 'assurer' and respectively), that is, to assure the observance of good faith. The Russian and Chinese texts both follow the structure of the English version.

We are aware of opinions, both among scholars ${ }^{24}$ and courts, ${ }^{25}$ that do not interpret Article 7(1) in the manner that we suggest. Will people continue to interpret Article 7(1) differently? Almost certainly. Is that a fatal flaw that condemns the CISG as a failure? No. Admittedly it is frustrating, but it is not an insurmountable, or even unexpected, problem.

\footnotetext{
${ }^{23}$ Schlechtriem and Schwenzer, above n 20, 95 para 7 (Art 7) (emphasis added and citations omitted).

${ }^{24}$ Nives Povrzenic, Interpretation and gap-filling under the United Nations Convention on Contracts for the International Sale of Goods, (1998) CISG Database

$<$ http://www.cisg.law.pace.edu/cisg/biblio/gap-fill.html> at 11 August 2009.

${ }^{25}$ Judgment of Nov 17, 1995, Arb Ct CCI Budapest (Mushrooms case), CISG-online 250

$<$ http://www.cisg-online.ch/> at 11 August 2009; Judgment of May 10, 2000, Corte

Constitucional de Colombia, CISG-online $250<\mathrm{http} / /$ www.cisg-online.ch/> at 11 August 2009; Judgment of Nov 30, 1998, Compromex [Comisión para la Protección del Comercio Exterior de México = Mexican Commission for the Protection of Foreign Trade], CISG-online $504<$ http://www.cisg-online.ch/> (Dulces Luisi v Seoul International).
} 


\section{B Language Problems}

The second basis on which Scheaffer suggests that the CISG has suffered is that of language difficulties. Here again, though we understand and appreciate the thrust of this argument, we believe the issue has been mischaracterised. This mischaracterisation then influences Scheaffer's proposed solution, which does not in our view resolve the real underlying problem.

In our view the issue is more accurately understood as one of differing legal concepts, rather than simply differing languages. Without in any way intending to understate the difficulties of translating from one language to another, we think the translation of legal concepts is harder. This difficulty is perhaps most easily demonstrated within the same language. Article 16 of the CISG distinguishes between 'withdrawal' and 'revocation'. An offer can be 'withdrawn' before it has been received by the offeree. Once received, and before acceptance, the offer can, subject to some exceptions, be 'revoked'. The word used changes depending on whether the offer has been received. In contrast, under English law, the word 'withdrawal' is used for situations up to the acceptance of the offer. Whether the offer has been received or not does not influence the word used. ${ }^{26}$ Thus the problem is not simply a linguistic one but rather a conceptual one - made even more complicated by the six official languages.

A problem of this kind cannot be avoided. It is a problem that affects every international treaty or convention. Efforts must therefore be focused on ways of overcoming its effects. Certainly, the UN in general (and UNCITRAL in particular) is aware of this problem and has adopted processes to minimise the problems associated with it. One such process is simultaneous translation. Describing the 1980 Vienna Conference in his 1986 text, Professor Schlechtriem observes that '[the CISG] was written and certified in the following official languages: Arabic, Chinese, English, French, Russian and Spanish. The discussions were all conducted in one of these languages and then translated simultaneously into the other five'. ${ }^{27}$ Simultaneous translations are not a complete solution but they certainly serve to lessen the problem in so far as they allow the delegates a contemporaneous opportunity to debate the relevant concepts. We acknowledge that, in the particular case of the CISG, anecdotal evidence suggests that simultaneous translation did not occur as

\footnotetext{
${ }^{26}$ The classic English authority that an offer can be withdrawn at any time prior to acceptance is Offord v Davies (1862) 12 CB NS 748. For more recent authority see Scammell v Dicker (2001) 1 WLR 631 and Flynn $v$ Scougall [2004] EWCA Civ 873 [18].

${ }^{27}$ Peter Schlechtriem, Uniform Sales Law - The UN-Convention on Contracts for the International Sale of Goods (1986) 20.
} 
thoroughly as it would today. Another way of addressing this problem is for the drafters to explain concepts using terms not normally found in domestic law or in a way clearly distinguishable from their domestic law use. This was certainly the intention of the CISG drafters.

Scheaffer raises two specific examples to argue his case for language problems. In our view the first of these is unsustainable; the second we alluded to above and acknowledge is a difficulty, but it is one which can be overcome.

The first example Scheaffer refers to is the Argentinean version of the CISG,

It is impossible to expect that each version of a multi-language treaty precisely corresponds to others. Replicating terms consistently in two languages, let alone six, is a difficult feat. This is exemplified by the Argentinean version of the CISG, which at adoption, contained a typographical omission in Article 2, that would have made the CISG applicable to consumer sale and other transactions expressly excluded under the Convention. ${ }^{28}$

Scheaffer cites an article by Felemegas on this point. ${ }^{29}$ However, Felemegas had cited Kastely. ${ }^{30}$ Kastely explains that the omission did not occur in the official Spanish version of the CISG. This is an example of a transcription error, not a translation error. It occurred in one language, in this instance Spanish, but could just as easily have occurred in English.

Scheaffer's second example refers to an article published by Professor Harry Flechtner. $^{31}$ In his article Flechtner recalls an argument he had previously made about how Articles 71 and 72 CISG should be interpreted. He notes that he had made this argument on a textual analysis of the English version of the CISG. In the English version the two Articles use different descriptive words, which Flechtner argued implied different standards. Sometime later, when reviewing the French version, he noticed that the same descriptive words had been used in both Articles 71 and 72. This, he acknowledges, 'undercut' (though it did not defeat) his earlier argument, but he decided that that

\footnotetext{
${ }^{28}$ Scheaffer, above n 4, 474.

${ }^{29}$ John Felemegas, 'The United Nations Convention on Contracts for the International Sale of Goods: Article 7 and Uniform Interpretation' [2000-2001] Review of the Convention on Contracts for the International Sale of Goods 115.

${ }^{30}$ Amy Kastely, 'Unification and Community: A Rhetorical Analysis of the United Nations Sales Convention' (1988) 8 Northwestern Journal of International Law and Business 574, 592.

${ }^{31}$ Harry Flechtner, 'The Several Texts of the CISG in a Decentralized System: Observations on Translations, Reservations and other Challenges to the Uniformity Principle in Article 7(1)' (1998) 17 Journal of Law and Commerce 187.
} 
particular journal article was not the place to answer the question. Flechtner notes that one (albeit not entirely satisfactory) way of resolving the issue might be to examine the other official versions. ${ }^{32}$ We have done that. It is interesting to note that the Spanish, Arabic, Russian and Chinese versions all use different descriptions in the respective Articles, tending to support Flechtner's original interpretation of the English version.

As noted above we believe that the 'language' issue is better characterised as a conceptual issue rather than a pure language one. We feel that focusing on the different national languages is a flawed approach in the sense that it cannot offer a solution. This is so for two reasons. First, it is unrealistic to think that the world will have a single 'legal' language anytime soon. English may appear to be the international lingua franca at the moment, but, as history shows, there is no certainty that it will remain so. Second, as our earlier example involving 'withdrawal' and 'revocation' demonstrates, the problem still exists within a single language in any event.

While we say that the problem is better understood as a conceptual one, we appreciate that it cannot be divorced from the differing national languages. Therefore we believe that the solution must involve all the differing languages rather than just one.

\section{C 'Opting Out' of the CISG}

Scheaffer's third basis of criticism comes from what he alleges are the multitude of 'mini-codes' emerging from the CISG. ${ }^{33}$ A closer analysis of the statistics relied upon to make this allegation reveals that this argument is also unsustainable.

The CISG has been adopted by 74 countries. ${ }^{34}$ This makes the Convention one of the most successful instruments in the area of private law worldwide ${ }^{35}$.

\footnotetext{
${ }^{32}$ Flechtner observes that this approach would be quite unhelpful in the particular case he described in his text.

${ }^{33}$ Scheaffer, above n 4, 464.

${ }^{34}$ See United Nations Convention on Contracts for the International Sale of Goods, Status 1980 (2009) <http://www.uncitral.org/uncitral/en/uncitral_texts/sale_goods/1980CISG_status.html> at 11 August 2009.

${ }^{35}$ See, eg, Loukas Mistelis, CISG-AC Publishes First Opinions (2008) Pace Law School Institute of International Commercial Law <http://www.cisg.law.pace.edu/cisg/CISGAC.html> at 11 August 2009: 'It is often pointed out that, world-wide two thirds of international sale transactions are conducted between parties based in a CISG country'; and
} 
It is true that the Convention gives each adopting country the opportunity to make declarations or reservations. However, it is not accurate to suggest that $30 \%$ of the contracting states have consequently created a series of 'mini codes'. An examination of the actual declarations and reservations made is necessary.

The UNCITRAL website (Status of the Convention) ${ }^{36}$ reveals that only eleven countries $^{37}$ have made a reservation to Articles 12 and 96 of the Convention. The reservation is to the effect that any provision of Article 11, Article 29 or Part II of the Convention that allows a contract of sale or its modification or termination by agreement or any offer, acceptance or other indication of intention to be made in any form other than in writing, would not apply where any party had his place of business in its territory. Eleven countries constitute approximately $14 \%$ of the adopting countries. While any change to treaty provisions is important, this reservation cannot really be considered as creating a mini-code.

Only seven countries, ${ }^{38}$ that is, fewer than $10 \%$, have made a reservation relating to the application of Article 1(1)(b). Article 1(1)(b) states that the CISG will apply where the rules of private international law point to a contracting state.. This is also a minor reservation since the reciprocity reservation common in most international instruments does not have a substantial effect in a Convention that has already been adopted by 74 countries. Indeed, as the number of contracting states increases, the significance of this reservation diminishes. ${ }^{39}$

The only countries that have really opted out of a significant part of the Convention are Denmark, Finland, Norway and Sweden, four countries representing less than $6 \%$ of the whole. These countries declared that they would not be bound by Part II of the Convention ('Formation of the

Hiroo Sono, Contract Law Harmonization and Non-Contracting States: The Case of the CISG (2008) Pace Law School Institute of International Commercial Law <http://www.uncitral.org/pdf/english/congress/Sono_hiroo.pdf> at 11 August 2009.

${ }^{36}$ See United Nations Convention on Contracts for the International Sale of Goods, Status 1980 (2009) <http://www.uncitral.org/uncitral/en/uncitral_texts/sale_goods/1980CISG_status.html> at 11 August 2009.

${ }^{37}$ Argentina, Belarus, Chile, Hungry, Lebanon, Lithuania, Paraguay, Russian Federation, Ukraine, China.

${ }^{38}$ China, Czech Republic, Germany, Saint Vincent and the Grenadines, Singapore, Slovakia and the United States.

${ }^{39}$ The application of Art 1(1)(a) CISG is not impaired by Art 95 CISG; Filanto SpA $v$ Chilewich International Corp, (SDNY Apr 14, 1992) 984 F2d 58, CISG-online 45. Contra Judgment of May 26, 1998, OLG Thüringen, CISG-online 513 (Germany). 
Contract') and that they would not apply the Convention to contracts of sale where the parties have their places of business in Denmark, Finland, Iceland, ${ }^{40}$ Sweden or Norway. It is rumoured that these countries will effectively opt-back in the near future.

\section{Misapplication of the CISG by Courts}

We agree with Scheaffer that many domestic courts have taken a 'homeward trend ${ }^{41}$ approach. The term 'homeward trend' is generally understood to mean that the CISG has been interpreted through the prism of domestic law. In other words courts have interpreted the CISG as though it were the same as their respective domestic laws. We also agree that this is unfortunate, but we question whether this is a fair measure to determine the success or failure of the CISG. It seems to us that those who cite this as a failure of the CISG are often applying an unrealistic standard in assessing its effectiveness. For example, do conflicting - or even wrong - interpretations of the Uniform Commercial Code (UCC) prompt allegations of failure? No. ${ }^{42}$ While it is certainly desirable that conflicting decisions be avoided, they are not unexpected. It may be that the level of conflicting decisions could rise to the level of a failure, but we do not believe that level has yet been reached.

\section{E Internal Contradictions}

In his introduction Scheaffer makes brief mention of alleged internal contradictions in the CISG. In a footnote he identifies Articles 14(1) and 55 as an example of such a contradiction. ${ }^{43}$

Scheaffer's opinion is that there is contradiction between these Articles. The former requires that an offer, in order to be valid, must expressly or implicitly fix or make provision for determining the quantity and the price. The latter, on the other hand, states that where price is not set by the parties, the price will

\footnotetext{
${ }^{40}$ Iceland in reciprocity declared that it would not apply the Convention.

${ }^{41}$ Scheaffer, above n 4, 477.

${ }^{42}$ See, eg, Colin Marks, 'The Limits of Limiting Liability in the Battle of the Forms: U.C.C. Section 2-207 and the “Material Alteration” Inquiry' (2006) 33(3) Pepperdine Law Review 501, who discusses the varying approaches courts have understood Section 2-207 of the UCC.

${ }^{43}$ Scheaffer, above n 4, 7.
} 
be that which is generally charged at the time of contracting for those goods sold under comparable circumstances in the trade concerned. This does not mean, however, that 'it would be impossible for a court to determine whether a stated price is required for a contract to exist where one part of the code says it must be included but another gives a remedy for a situation where parties fail to agree on that price'. ${ }^{44}$ The word 'impossible' is too strong.

The relationship between these two Articles has spawned considerable amounts of commentary. ${ }^{45}$ One view is that the Articles work in harmony with the different approaches taken by national laws: those that support open price offers and those that required the price to be definitive. ${ }^{46}$ It should be remembered that Article 55 is within the third part of the CISG and was specifically created to avoid situations where a state declares a reservation relating to Part II of the Convention. Countries doing so (as the Scandinavian countries did) would otherwise be left with a CISG without any rules on contract formation. Therefore, on one view, the purported contradiction is baseless, because there is a single rule stating that every contract always contains either an express or an implied price. A price could be fixed in two ways. The first is by including a provision in the offer determining the price, or a mechanism for determining the price. Alternatively, when the parties have not discussed a price, Article 55 would function as an interpretative guideline to determine an implied price, namely the price that would generally be charged at the time of the conclusion of the contract for such goods sold under comparable circumstances in the trade concerned. In addition, Article 55 is important when the Convention is to be applied without Part II and the applicable domestic law permits a contract to be concluded without specifying a price. ${ }^{47}$

So, concluding this part of the article and summarising our critique of Scheaffer's arguments, we agree that there are difficulties and issues to be overcome. We disagree that these are failings and we disagree with the way Scheaffer has characterised many of the difficulties. Finally, we assert that these mischaracterisations have led Scheaffer to propose unrealistic solutions. In the next part we identify the reasons why we believe Scheaffer's solutions are unrealistic.

\footnotetext{
${ }^{44}$ Ibid.

${ }^{45}$ For a discussion of the differing views see Schlechtriem and Schwenzer, above n 11, 194 para 10 (Art 14).

${ }^{46}$ Ibid.

${ }^{47}$ Ibid 195 para 11 (Art 14).
} 


\section{PART II: THE IMPEDIMENTS TO SCHEAFFER'S NEW GLOBAL CODE}

When introducing his idea of a new Global Code, Scheaffer suggests the use of the UCC as a guide to its creation. Although there is some ambiguity in the headings used, we do not understand Scheaffer to mean that the proposed code should be based on the UCC. The problems with this approach would be obvious. From a pluralistic perspective it would be unheard of to limit the content of a 'global' code to the principles of a common law country, thereby leaving aside other legal families such as the civil law and religious legal systems, for example. It is not enough that the UCC has proven successful within the United States. International instruments in private law require more than one good law example.

Rather, we understand Scheaffer to be referring to the desirability of learning from the experience of the UCC. He emphasises three aspects of this experience. The first is the respect of one jurisdiction for the decisions of another which can be seen in UCC decisions. He believes that, although not binding, judicial decisions from other countries would be persuasive. It is not clear how this would be the case. If a reliance on international comity is required, then how would this position differ from what presently exists? Would the new code place a positive obligation on the courts of each country to consider the decisions of other courts in other countries? Would there be a doctrine of precedent? Even adopting the more liberal understanding of that doctrine found in the United States, ${ }^{48}$ there would be issues with court hierarchies.

The second experience of the UCC that Scheaffer highlights is the official commentary which accompanies it and which assists in the interpretation of its terms. We agree that such a commentary on the proposed Global Code would be very helpful, however we believe it would be near to impossible to establish. ${ }^{49}$ We explain our reasons for this view in detail below in the context of the CISG Advisory Council. However, it is necessary at this point to address Scheaffer's example of the UNIDROIT Principles (PICC). In the footnote that accompanies this example, Scheaffer acknowledges that the PICC 'are not actually binding law'. ${ }^{50}$ In our view this makes all the

\footnotetext{
${ }^{48}$ For a comparison of the doctrine of precedent in England versus the United States see Anika Stucky, 'Building Law, Not Libraries: The Value of Unpublished Opinions and Their Effects on Precedent' (2006) 59(2) Oklahoma Law Review 403.

${ }^{49}$ In any event there is the Secretariat's Commentary on the CISG which may not be an official commentary in the sense of a Restatement or the like, but is quite close to it.

${ }^{50}$ Scheaffer, above n 4, 481 note 111.
} 
difference. Reaching agreements on hypotheticals and non-binding guidelines is an entirely different ball game, as it does not involve anywhere near the level of politics involved in domestic negotiations. Later in his article, Scheaffer suggests that the drafters of the new Global Code should have regard to the PICC. This is actually a statement in favour of the CISG. To quote Bonell, Chairman of the Working Group for the preparation of the UNIDROIT Principles of International Commercial Contracts, '[t]o the extent that the UNIDROIT Principles address the same issues as the CISG, their provisions are normally taken either literally or at least in substance from the corresponding provisions of the CISG ${ }^{, 51}$

The third experience of the UCC is its relatively uniform adoption by the various States of the US. At the time of adoption these States were able to make amendments if they desired. A number of States did so, though most amendments were minor. It is not entirely clear why, then, Schaeffer makes this point, as it seems to weaken rather than strengthen his argument. We have already responded to the assertions regarding 'mini codes' above. Those comments apply equally here.

To support the maintenance of the system produced by the Global Code, Scheaffer suggests the creation of an international advisory council. This council would 'issue advisory opinions and rectify ambiguities with the Global Code'. ${ }^{52}$ Scheaffer does correctly identify the arguments of the critics of this approach and then posits a response to those arguments. Thus, we find ourselves in the advantageous position of essentially providing a rebuttal. Scheaffer suggests that critics ignore the success of institutional bodies such as UNIDROIT and the Hague Conference on Private International Law. With respect, we fail to see the relevance of this observation, as neither of these institutions is empowered to make binding amendments to laws. An ability to issue binding amendments would presumably be necessary to 'rectify ambiguities'.

Scheaffer then suggests that his strongest argument is that 'a limited council for international sales law is already in existence and has been issuing advisory opinions for a number of years under the guidance of UNICTRAL ${ }^{53}$ Here he is referring to the CISG Advisory Council. The statement is fundamentally wrong. The CISG Advisory Council does not operate under the guidance of UNICTRAL. It is a private initiative originally

\footnotetext{
${ }^{51}$ Michael Bonell, 'The CISG, European Contract Law and the Development of a World Contract Law’ (2008) 56 American Journal of Comparative Law 1, 17.

${ }^{52}$ Scheaffer, above n 4, 482.

${ }^{53}$ Ibid.
} 
promoted by the Institute of International Commercial Law, Pace University, and the Centre for Commercial Law Studies at Queen Mary, University of London. ${ }^{54}$ UNCITRAL is not part of the CISG Advisory Council and does not attend council meetings. The CISG Advisory Council is possible precisely because it is not official. (This observation relates to our earlier response to the suggestion of an official commentary.) An official body capable of amendment by decree would inevitably become political and unworkable. Most significantly, it would require diplomacy and, at best, muted critiques. UNCITRAL and other UN creations exist in a highly charged diplomatic and political environment. UNCITRAL could not been seen to countenance any criticism of any UNCITRAL member.

The general idea of an advisory council is a good one. To date the independent CISG Advisory Council has issued 7 opinions. ${ }^{55}$ These opinions have an intrinsic value and have indeed been used by courts when determining CISG cases. ${ }^{56}$ However, a 'Permanent Editorial Board' (PEB) of the sort Scheaffer suggests, that is, one which would edit and add provisions to the new Global Code, would not have the expected success. Whether the proposed Global Code takes the form of a model law or a convention, each time an amendment or addition is proposed by the PEB a new legislative process in each member country has to be undertaken. The experience of the UNCITRAL working groups - for example the group relating to the Model Law on International Commercial Arbitration - is that individual governments only start considering the possibility of adopting the modifications proposed after two or three years. ${ }^{57}$ To overcome this problem the PEB would need to

\footnotetext{
${ }^{54}$ See Loukas Mistelis, CISG-AC Publishes First Opinions (2008) Pace Law School Institute of International Commercial Law <http://www.cisg.law.pace.edu/cisg/CISG-AC.html > at 11 August 2009 and in German: Rolf Herber, Eine neue Institution: Der CISG Advisory Council, $<$ http://www.globalsaleslaw.org/_temp/CISG-_AC_Herber_intro.pdf > at 11 August 2009 Prof Herber was head of the German delegation at the Vienna conference.

${ }^{55}$ Available at CISG - Advisory Council, Opinions (2008) <http://www.cisgac.com/> at 11 August 2009.

${ }^{56}$ TeeVee Tunes Inc v Gerhard Schubert GmbH, CISG-online 1272 (SDNY, 2006) $<$ http://cisgw3.law.pace.edu/cases/060823u1.html> at 11 August 2009.

${ }^{57}$ On December 4, 2006 the General Assembly of the UN passed Resolution 61/33 which integrated the amendments and additions made to the Model Law on International Commercial Arbitration of 1985. At the time of writing just four countries have integrated such changes into their legislation. One might also analogise directly with the UCC and note that the 2003 Revision of Article 2 has only been adopted by the US Virgin Islands - which is, in any event, not a State of the USA.
} 
be vested with the power to unilaterally make changes from the inception of the Code. We believe that countries are very unlikely to grant such a power. ${ }^{58}$

Similar difficulties would appear with the establishment of an International Court. ${ }^{59}$ We must consider not only the normal managerial tasks for the creation and administration of such a Court, but also the fact that most legal systems have established constitutional rules for the application of court precedents and jurisprudence. Not all jurisdictions endow all their courts with the same jurisdictional power. Most countries have specific rules regarding the binding nature of a court decision. Therefore, not only would amendments be needed in each legal system in order for the authority of an international court to be recognised, but also a harmonised and uniform system of interpretational rules and precedents would be necessary within the International Court.

We next take issue with the suggestion that one official language version of the proposed Code should prevail over the others in cases of inconsistency. Scheaffer suggests that there would still be other official language versions, but the implication is that ultimately English would be the controlling language. We believe that this would be practically the same as deciding that there would be only one official version.

English is the most appropriate language in which to communicate the Global Code principles to those who speak English and are familiar with the English terminology of trade and trade law. However, not everyone involved in sales contracts or in related disputes is knowledgeable in English. It seems unrealistic to believe that the English version of the new Global Code would be the one consulted by judges who cannot speak the language. Indeed, looking at the experience of the CISG in German-speaking courts, reference is usually had to the unofficial German version, though one notable exception has been the practice of the Swiss Federal Court. ${ }^{60}$

\footnotetext{
${ }^{58}$ Naturally, we cannot say for certain that countries would not sign up to a convention with this sort of delegated authority. There are arguably examples of it already. The Convention on the Settlement of Investment Disputes between States and Nationals of Other States 1966 (also known as the ICSID or Washington Convention) could be cited as it provides a mechanism for some amendment. Article 6 effectively delegates certain powers of amendment to the Administrative Council. However, it must be noted that the Administrative Council is made up of a representative of every contracting state, and the delegated authority is limited.

${ }^{59}$ Scheaffer, above n 4, 483.

${ }^{60}$ Judgment of May 12, 2003, Obergericht des Kantons Luzern, CISG-online 846 (Switzerland).
} 
An inability of judges (and of jurists in general) to work with a unique English version would lead to a proliferation of unofficial translations, considerably increasing the risk of mistranslations (and consequently misinterpretation). To have six equally official versions would reduce this risk. For example, all Spanish-speaking countries have adopted the same authentic Spanish text of the CISG, rather than translating it with their own dialectical differences. ${ }^{61}$ Furthermore, almost every national constitution or procedural code guarantees that all trials and proceedings may be conducted in the official language of the country. Arguably these laws would need to be amended if there was only one official English version.

Moreover, according to the organisational rules of the United Nations, the Secretary-General has to ensure equal treatment of the six official languages of the United Nations. ${ }^{62}$ Consequently, any new text, instrument, convention, or official document should be translated into all the six official languages of the United Nations: English, Spanish, Chinese, Arabic, French and Russian. This would make it impossible for UNCITRAL to produce a single official English version of the proposed Global Code, unless the 'equal treatment' principle were also reformed.

To the extent that we agree with Scheaffer's criticisms of the CISG, we cannot see how the proposed Global Code addresses those concerns. Indeed, we think it more problematic than the CISG. Even if absolute agreement could be reached among the experts involved in its drafting, it is difficult to see how a Global Code adoption process involving the entire world would be as easy as it was for the UCC. This is not only because of political arguments concerning sovereignty, but because of the myriad of linguistic, infrastructure, legal and cultural issues it would raise.

The CISG is not a perfect instrument. However, its general acceptance gives it sufficient authority for it to continue. We certainly agree with Scheaffer when he suggests that the solution lies in 'building upon the current state of the CISG ${ }^{63}$ However, we do not believe that starting from scratch is the way to go.

\footnotetext{
${ }^{61}$ Twelve Spanish speaking countries are member states of CISG in the version published by the UNCITRAL: Argentina, Chile, Colombia, Cuba, Ecuador, El Salvador, Honduras, Mexico, Paraguay, Peru, Spain and Uruguay: see above $\mathrm{n} 36$.

${ }^{62}$ Djamel Moktefi, Pattern of Conferences, UN GAOR, $5^{\text {th }}$ Comm, $52^{\text {nd }}$ sess, Agenda Item 119, UN Doc A/52/734 (1997).

${ }^{63}$ Scheaffer, above n 4, 466.
} 
Our position can be summarised as follows. We believe in the aspirational goal of establishing an environment which promotes international trade by lowering transaction costs. Predictability is a fundamental need in such an environment. One uniform law applied with absolute uniformity throughout the world would provide predictability. However, the completely uniform application of such a law is unrealistic and, in any event, undesirable. It would be impossible to draft such a law without necessarily and severely restricting party autonomy and freedom of contract. Rather, the law should be the framework upon which individually nuanced contracts could be built. It should provide solutions to the disputes that arise between parties, if the parties themselves have not already determined a solution. Predictability is obtained by developed and established avenues of communication. It is also obtained by developing and establishing means of explaining and understanding the concepts upon which the framework has been built. This, then, is not simply a linguistic issue. A conceptual translation tool is required.

\section{PART III: OTHER HARMONISATION EFFORTS}

To support our assertion that a new Global Code introduced as a legal statute is not a realistic idea, we can consider the experience of other relatively recent harmonisation efforts.

As noted above, international instruments such as the PICC have been developed in an attempt to progressively harmonise the rules of law for international commercial contracts. It is often argued that, along with the Principles of European Contract Law (PECL), the PICC are part of a new lex mercatoria.

The PICC have proven to be a successful avenue of harmonisation. Soon after their publication in 1994 court decisions and arbitral awards were already applying the principles to international contracts. ${ }^{64}$ Also, the great volume of scholarship produced during the past fifteen years, on both the 1994 and the 2004 versions, has contributed to their understanding and promoted their application.

\footnotetext{
${ }^{64}$ Michael Bonell, 'The UNIDROIT Principles of International Commercial Contracts and the Principles of European Contract Law: Similar Rules for the Same Purposes?' (1996) 26 Uniform Law Review 229 <http://www.cisg.law.pace.edu/cisg/biblio/bonell96.html> at 11 August 2009.
} 
The CISG and the PICC share similarities and contain differences that make them compatible in their potential combined application to a single contract.

On the one hand, the CISG deals with the international sale of goods, while the PICC cover contracts in general. But they have many other things in common. Both are concerned with international, not domestic contracts, and B2B contracts, not B2C contracts. ${ }^{65}$ Many of the rules of the CISG and of the PICC are the same or similar - for example, those in the CISG on the formation of the sale contract and PICC Chapter 2 on the formation of contracts in general. Likewise, while CISG Part III covers the content and the breach of the sales contract, the PICC deal with the same issues for contracts in general in Chapters 5, 6 and 7, with important similarities in structure and content.

The provisions of the PICC which the CISG does not have are broadly compatible with the CISG and can be integrated by party choice as the law applicable to particular areas of a contract without disturbing the rules of the CISG. This is especially true, for example, of the provisions of the PICC on the validity of contracts.

Nevertheless, and most importantly, both PICC and PECL remain soft law. They are sets of rules with no binding character unless the parties expressly or impliedly confer binding force on them to govern a particular contract. Courts and arbitrators may not generally apply the PICC unless contracts are subjected to them, or unless the forum law allows the judge or arbitrator to settle the dispute with due regard to the international principles on contract. The CISG, on the other hand, has direct application to all international sales of goods between parties domiciled in a Member State, unless expressly excluded by them. ${ }^{66}$

\footnotetext{
${ }^{65}$ B2B stands for transactions between one business and another business while B2C stands for transactions between, on the one hand, a business, and, on the other hand, a consumer.

Generally, in B2C transactions, special rules of law are deployed in order to protect the weaker party in the transaction.

${ }^{66}$ See United Nations Convention on Contracts for the International Sale of Goods art 1(a), (b) and art 6.
} 


\section{Part IV: An Alternative Solution - The Global Sales Law PROJECT}

The Global Sales Law project is the initiative of Professor Ingeborg Schwenzer and is run from the University of Basel, Switzerland. Professor Schwenzer's name will be well known to those who have had any interaction with the CISG. Throughout this article we have already cited the commentary she edited with the late Professor Schlechtriem. ${ }^{67}$ She is now the sole editor of that commentary, which is widely acknowledged as a seminal text in this field. Professor Schwenzer is also a member of the CISG Advisory Council referred to earlier.

In Professor Schwenzer's view the CISG is only part of a solution. As the CISG critics note, the convention contains gaps and does not deal with certain aspects of the sales transaction at all. This means that recourse is often had to domestic sales law. What was therefore required was a comprehensive study of sales laws from around the world, in essence a resumption of the work Ernst Rabel began more than 70 years ago. ${ }^{68}$ This is the motivation behind the Global Sales Law project.

The project has been made possible by initial funding from the Swiss National Fund, the Freiwillige Akademische Gesellschaft, the Max-Geldner-Stiftung and the Stiftung zur Förderung der rechtlichen und wirtschaftlichen Forschung an der Universität Basel. To enable the undertaking of a genuinely comparative study, a team of researchers made up of native speakers of each of the UN languages as well as native speakers of German, has been assembled. As noted in the introduction, we are both members of that team. The research conducted over the next two and a half years will culminate in a handbook. The purpose of this handbook is to forge a global view of international sales law today.

In the context of this article, one particular aspect of the overall project will be explained, as it relates directly to the language and conceptual difficulties we referred to above.

\footnotetext{
${ }^{67}$ Schlechtriem and Schwenzer, above $\mathrm{n} 11$.

${ }^{68}$ Ernst Rabel, Das Recht des Warenkaufs : Eine rechtsvergleichende Darstellung des KaiserWilhelm-Instituts für ausländisches und internationales Privatrecht ; vol 1 (1936); vol 2 (1957).
} 


\section{A The Global Sales Law Thesaurus}

Developing an efficient and effective method of managing the collective knowledge and research generated was a critical first step of the project. When considering this issue it became apparent that many of the language and conceptual difficulties that plague a multilingual convention could also plague our research. A system that would enable us to genuinely compare like concepts and contrast unlike concepts was necessary. To make such comparisons we needed some sort of common point of reference to begin with - we needed a Rosetta stone. Our Rosetta stone came in the form of the CISG and other international instruments such as the UNIDROIT Principles (PICC) and the Principles of European Contract Law (PECL).

The CISG is the perfect Rosetta stone, notwithstanding the various language and conceptual difficulties that we have already outlined and acknowledged above. A fundamental assumption that can be made concerning a convention that has 6 official versions is that each version is intended to mean the same thing. The same is true of other instruments such as the PICC and PECL.

Each of these instruments has been analysed to indentify the legal concepts it contains. The precise wording used to explain the concept is then extracted in each language. This becomes the controlled vocabulary, through which it is hoped that the language of international sales law will achieve a level of uniformity. Rather than thinking in terms of differing national languages, the project participants are drawing a distinction between the language of International Sales Law and the languages of the domestic sales laws. This approach does not so much allow the equal treatment of each national language, but rather removes any distinction between them. The English expression of a particular international sales law concept is treated as an exact synonym of the Arabic expression of the same concept. Alternative terms, phrases and expressions used in the variety of legal systems around the world are mapped to the controlled vocabulary, based on their relationship with the legal concept, not the particular term used. The mapping process allows the international and domestic concepts to be distinguished. 
The box below demonstrates how the Thesaurus works.

\begin{tabular}{|c|c|}
\hline \multicolumn{2}{|c|}{ AVOIDANCE (CISG Eng) } \\
\hline $\mathrm{CT}$ & Résolution (CISG Fr) \\
\hline CT & Resolución (CISG Sp) \\
\hline CT & خسف (CISG Ar) \\
\hline CT & Расторжение (CISG Ru) \\
\hline $\mathrm{CT}$ & 无效 (CISG Ch) \\
\hline CT & Termination (PICC Eng) \\
\hline $\mathrm{CT}$ & Résolution (PICC Fr) \\
\hline \multicolumn{2}{|c|}{ Use For Rescission } \\
\hline \multicolumn{2}{|c|}{ Use For Cancellation } \\
\hline INE & Rücktritt (Germany) \\
\hline NNE & Rücktritt (Switzerland) \\
\hline NNE & Wandlung (Switzerland) \\
\hline NNE & Rescission (England) \\
\hline NNE & خسف (Egypt) \\
\hline NT & Notice of Avoidance \\
\hline NT & Declaration of Avoidance \\
\hline NT & Fundamental Breach \\
\hline $\mathrm{BT}$ & Remedies \\
\hline RTerm & Damages \\
\hline RTerm & Fundamental Breach \\
\hline
\end{tabular}

The example concept is 'avoidance' (CISG Eng). This exact concept has a corresponding term (CT) in another international instrument, the PICC. However there it is referred to in English as 'termination'. The 'Use For' field indicates non-preferred terms in the context of international sales law. It encourages the reader to use 'avoidance' rather than 'cancellation' when 
describing the concept as it exists in international sales law. The next relationship specified is 'Identical National Equivalent' (INE). This relationship identifies where exactly the same concept exists within the law of an individual country. In the above example the concept of 'Rücktritt' in German law is exactly the same as the concept of 'avoidance' in the CISG. In contrast, however, the concept of 'Rücktritt' in Swiss law is not quite the same. Because of this difference, its relationship is that of 'Nearest National Equivalent' (NNE). Similarly, the concept of 'rescission' in English law is not quite the same as the concept of 'avoidance' in the CISG, and thus it is linked as an NNE. The other relationships used in the example - 'Narrower Term' (NT), 'Broader Term' (BT) and 'Related Term' (RTerm) - are self explanatory.

It is expected that the Thesaurus will serve as an important tool for uniform interpretation, and will overcome the trials and tribulations of language difficulties. It is anticipated that the Global Sales Law Thesaurus will primarily operate in the following types of situations:

Scenario 1: A judge in Mexico types a term into the Global Sales Law (GSL) Thesaurus and can instantly identify that it refers to a different concept in international sales law than in the domestic Mexican law.

Scenario 2: Imagine a seller (Switzerland) is negotiating the terms of a contract to sell chairs to a buyer (Egypt). The seller sends the buyer the terms and conditions of the contract. The terms have a choice of law clause - 'this contract is governed by the laws of Switzerland', for example. There is a word or phrase in the terms and conditions that the Egyptian buyer does not understand. The buyer would type the German/French/Italian term into the Thesaurus and would get its equivalent in Arabic (or any of the other languages) and be told whether the international concept is the same as the domestic Egyptian one.

The Thesaurus itself will not explain the differences between international and national concepts. Its purpose is simply to alert the user to the fact that there is a difference. Each entry, however, will have a short scope note that will provide an indication of where further information regarding the difference can be found. References may be to commentaries, cases, statues and so forth.

Scenario 3: The GSL Thesaurus may also be used as a contract-interpretation tool, specifically integrated by parties into their international sales contracts. For example, parties may include clauses such as the following: 
(A) 'This is an international sales contract. When interpreting the meaning and definition of terms and obligations in this contract, regard should be had to the Global Sales Law Thesaurus (2010).' This clause may be used when parties want neutral, non-national, specific principles to apply to their contract. If the Thesaurus extract reproduced above were used, it would also be evident that German jurisprudence on 'Rücktritt' should be extremely persuasive regardless of the jurisdiction;

(B) 'This contract is governed by English law. When interpreting the meaning and definition of terms and obligations in this contract, regard should be had to the Global Sales Law Thesaurus (2010) and the meanings attributed to English law.' A clause of this kind could be used when any national law had been specifically chosen. The GSL Thesaurus would assist interpretation by effectively stating what a term did not mean.

So, in conclusion, the purpose of the Global Sales Law Thesaurus is to try and help establish uniform concepts in international sales law by promoting the use of particular terminology. That terminology (in any of the given languages) will, it is hoped, come to denote exactly the same concept.

\section{CONCLUSION}

It has not been our intention to argue that the CISG is a perfect instrument to be lauded and accepted by all. By our own standards it is not perfect; indeed we doubt whether a perfect instrument could ever exist. Rather, the CISG is an instrument with flaws and holes, but it is real and something to work from. Already 74 nation states have adopted the convention. The legal system relating to international sales law can certainly be improved, but the efforts to do so must be realistic and achievable. 